\title{
Suprascapular nerve entrapment by a spinoglenoid cyst
}

Figure Physical examination and MRI findings
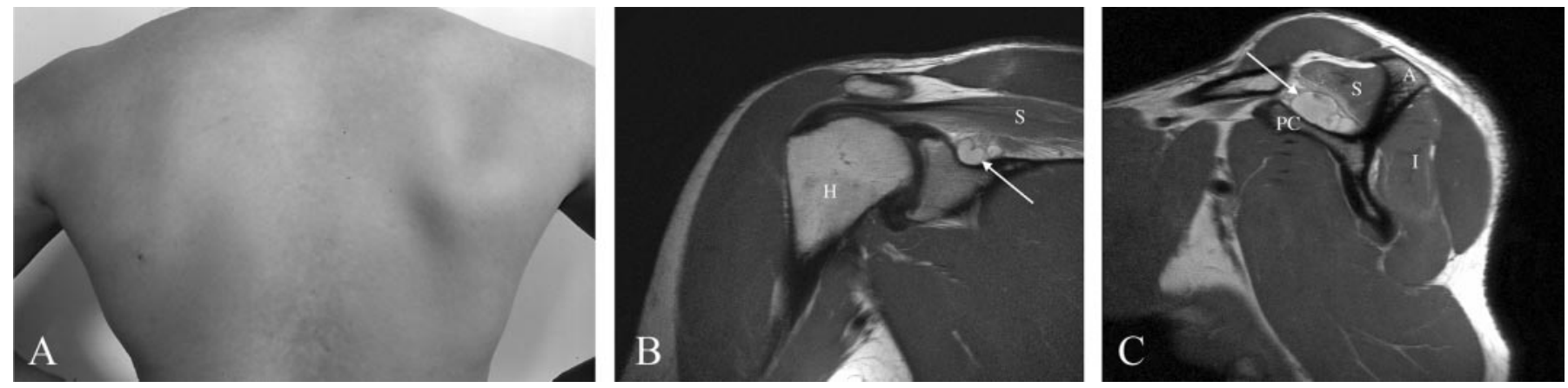

(A) Patient's back demonstrating the isolated atrophy of the infraspinatus muscle. (B, C) Proton density weighted images. (B) Coronal oblique image showing the cyst in the spinoglenoid notch. (C) Sagittal oblique image. Arrow: spinoglenoid cyst. $\mathrm{S}=$ supraspinatus muscle; $\mathrm{I}=$ infraspinatus muscle; $\mathrm{C}=$ coracoid process; $\mathrm{A}=$ acromion; $\mathrm{H}=$ humerus.

A 27-year-old body builder presented with a 1-year history of dull right-sided shoulder pain and proximal arm weakness. There was no history of neurologic complaints or shoulder trauma. Physical examination showed marked and isolated atrophy of his right infraspinatus muscle and an arm abduction paresis (MRC 3, figure, A). Deep tendon reflexes and sensation were normal. Electromyography showed fibrillation potentials and enlarged motor unit potentials confined to his infraspinatus muscle. MRI of the right shoulder revealed a large spinoglenoid cyst compressing the suprascapular nerve (figure, B and C). Six months after operative excision of the cyst the patient had regained normal musculature strength. Suprascapular nerve compression should be considered in cases of shoulder pain and arm abduction weakness. Electromyography and MRI are the methods of choice in depicting the etiology of this rarely encountered mononeuropathy. ${ }^{1}$

Alexander Semmler, MD, Marcus von Falkenhausen, MD, and Rolf Schröder, MD, Bonn (A.S., M.v.F.) and Erlangen (R.S.), Germany.

Disclosure: The authors report no conflicts of interest.

Address correspondence and reprint requests to Dr. Alexander Semmler, Department of Neurology, University Bonn, Germany; alexander.semmler@ukb.uni-bonn.de

1. Fritz RC, Helms CA, Steinbach LS, Genant HK. Suprascapular nerve entrapment: evaluation with MR imaging. Radiology 1992;182:437-444. 


\section{Neurology}

\section{Suprascapular nerve entrapment by a spinoglenoid cyst}

Alexander Semmler, Marcus von Falkenhausen and Rolf Schröder

Neurology 2008;70;890

DOI 10.1212/01.wnl.0000304748.02041.cd

\section{This information is current as of March 10, 2008}

Updated Information \&

Services

References

Subspecialty Collections

Permissions \& Licensing

Reprints including high resolution figures, can be found at: http://n.neurology.org/content/70/11/890.full

This article cites 1 articles, 0 of which you can access for free at: http://n.neurology.org/content/70/11/890.full\#ref-list-1

This article, along with others on similar topics, appears in the following collection(s):

All Clinical Neurology

http://n.neurology.org/cgi/collection/all_clinical_neurology

All Neuromuscular Disease

http://n.neurology.org/cgi/collection/all_neuromuscular_disease

EMG

http://n.neurology.org/cgi/collection/emg

MRI

http://n.neurology.org/cgi/collection/mri

Information about reproducing this article in parts (figures,tables) or in its entirety can be found online at:

http://www.neurology.org/about/about_the_journal\#permissions

Information about ordering reprints can be found online:

http://n.neurology.org/subscribers/advertise

Neurology ${ }^{\circledR}$ is the official journal of the American Academy of Neurology. Published continuously since 1951, it is now a weekly with 48 issues per year. Copyright . All rights reserved. Print ISSN: 0028-3878. Online ISSN: 1526-632X.

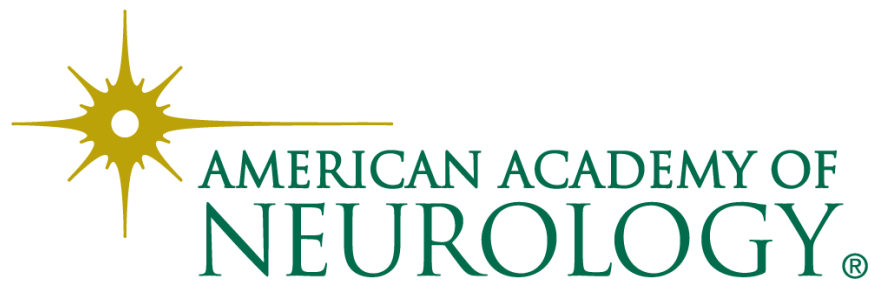

